\title{
UK redraws medical research funding
}

[LONDON] Britain's Medical Research Council (MRC) is introducing the biggest shakeup of its funding and peer review arrangements for university research for three decades.

According to MRC officials, the changes, whose details are being officially announced tomorrow (30 May), have been designed to encourage long-term, largE-scale multidisciplinary research in the biomedical sciences. They also contain schemes intended to provide long-term finance for scientists who are starting out on their research careers, as well as a fund for short-term, high-risk, speculative research.

Some of the changes are already proving controversial, in particular the decision to phase out grants for stand-alone projects (see Nature 387, 330; 1997). The MRC will reduce its funding for such activities from the next academic session, which begins in October. The grants, which currently fund 170 projects worth around $\mathfrak{E} 10$ million (US\$16 million) per year, will be phased out completely in 1998.

The MRC also plans to overhaul its research grant assessment system. Six existing grant application committees, each of them consisting of about 25 scientists, will be abolished. They will be replaced by a 200-member 'virtual' advisory board, primarily made up of existing committee members, but with a complement of new as well as younger scientists.

The changes will affect only the MRC's $\mathfrak{E 3 0 0}$ million budget for research proposals initiated by scientists. Known as 'response mode' funding, this represents around half of the council's total research spend. The council's funding arrangements for its own research facilities will remain unchanged.

George Radda, the MRC's chief executive, says that the restructuring has been introduced because advances in medical

\section{New MRC 'response mode' funding schemes}

\section{Centre grants}

Cooperative group grants

Development grants

Career establishment grants

Innovation grants research are more likely to emerge from collaboration between high quality, interdisciplinary teams than from lone investigators or small research groups. "There is now more collaboration between basic and clinical scientists. They need to be supported and adequately resourced," he says. Radda says forging a closer association between universities was part of the thinking behind the restructuring.

Under the new arrangements, researchers will be able to apply for five types of response mode research grant (see below). Applications for centre grants, cooperative group grants and development grants will be assessed on their merits by members of the new 200-member advisorybody.

Applications

for

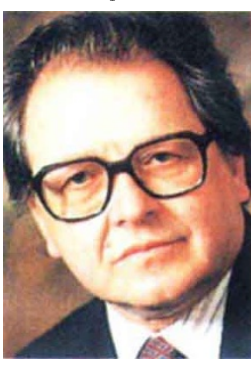

career establishment Radda: seeking boost grants will compete tolong-term efforts. directly with one

another, as will those for innovation grants. The former are intended, says Radda, to remove the uncertainty for new researchers who increasingly spend much of their early careers on a series of short-term contracts. Innovation grants are designed to protect speculative research.

The MRC, he says, will continue to provide support for "high quality" response mode applications in the form of 'programme grants'. Strategic programme grants made in response to specific initiatives will also continue as before, although in future they will also include funding for clinical trials under a subset fund known as 'trials grants'.

The proposals were drawn up by a small MRC working group after external consul-

Supporting research on a single university site. Five-yearly review. Sunset clause. Infrastructure provision.

Supporting collaborative research within or between universities in single geographical area. Minimum three projects, one can be non-MRC-funded. Five-yearly review.

Three-year, non-renewable grant for university to build up critical mass of research. 'Entry ticket' to cooperative grants.

Five-year, non-renewable support for research projects from newly appointed university scientists.

One-year funding for high-risk, speculative research.

Assessed from applicants' track record.

Twenty awards worth up to $£ 40,000$ each. tation. They were submitted for the first time to members of existing MRC grant committees at a discussion meeting held in London on 7 May.

The overall response appears to be positive. A member of one of the MRC's grant application committees sums up the views of many when he welcomes the plans as a "brave and constructive way forward".

"I'm particularly pleased that the MRC has maintained its commitment to response mode funding as opposed to going for more directed research," he says. "I also welcome the decision to ring-fence money for new researchers, so that they don't have to compete with experienced people."

This sense of relief, however, is tinged with some concern, particularly about the phasing out of funding for stand-alone projects. Some observers believe such a move will discriminate against high-quality researchers who are not necessarily linked to a large group or an élite institution. They also feel that it would reinforce the demarcation between 'research only' and 'teaching only' universities.

"The new proposals seem to consolidate the concept of 'centres of excellence," said one member of an MRC grant committee. "British science has thrived from work done in small groups. We've had some great ideas from lone scientists. I'm a bit fearful that this type of 'string and sealing wax' science will disappear."

Others have privately expressed a degree of concern at the apparent lack of formal consultation with relevant and interested groups. The Committee of Vice-Chancellors and Principals of UK universities, for example, said it was unable to comment on the changes as it did not have enough time to consider the details.

A similar response came from the 100member Association of Medical Research Charities (AMRC), which funds around $\mathfrak{£ 3 4 1}$ million of medical research in the United Kingdom per year. Diana Garnham, the AMRC's general secretary, says that the $\mathrm{MRC}$ restructuring plans seem to consolidate an existing trend in both the charity and public sector, as both the MRC and medical research charities have already cut back on stand-alone project funding.

Radda strongly denies the suggestion that the new schemes will lead to the concentration of research funds among a handful of universities. He points out that highachieving scientists from smaller universities will still be funded, for example, if they choose to join the cooperative group grant scheme. On the question of consultation, Radda says "it was not possible to consult 100 universities and every medical research charity".

EhsanMasood 